\title{
Common Variable Immunodeficiency and Circulating $\mathbf{T}_{\mathbf{F H}}$
}

\author{
Ana Coraglia, ${ }^{1}$ Nora Galassi, ${ }^{2}$ Diego S. Fernández Romero, ${ }^{3}$ M. Cecilia Juri, ${ }^{3}$ \\ Marta Felippo, ${ }^{2}$ Alejandro Malbrán, ${ }^{3}$ and María M. E. de Bracco ${ }^{1,2}$ \\ ${ }^{1}$ Instituto de Investigaciones Hematológicas (IIHEMA), Academia Nacional de Medicina, \\ C1425ASU Ciudad Autónoma de Buenos Aires, Argentina \\ ${ }^{2}$ IMEX-CONICET, Academia Nacional de Medicina, C1425ASU Ciudad Autónoma de Buenos Aires, Argentina \\ ${ }^{3}$ Unidad de Alergia, Asma e Inmunología Clínica, C1035AAT Ciudad Autónoma de Buenos Aires, Argentina
}

Correspondence should be addressed to Nora Galassi; ngalassi@hematologia.anm.edu.ar

Received 3 December 2015; Revised 15 February 2016; Accepted 22 February 2016

Academic Editor: Teresa Espanol

Copyright (C) 2016 Ana Coraglia et al. This is an open access article distributed under the Creative Commons Attribution License, which permits unrestricted use, distribution, and reproduction in any medium, provided the original work is properly cited.

\begin{abstract}
CD4+ $\mathrm{T}$ follicular helper cells $\left(\mathrm{T}_{\mathrm{FH}}\right.$ ) were assessed in adult patients with common variable immune deficiency (CVID) classified according to the presence of granulomatous disease (GD), autoimmunity (AI), or both GD and AI (Group I) or the absence of AI and GD (Group II). $\mathrm{T}_{\mathrm{FH}}$ lymphocytes were characterized by expression of CXCR5 and PD-1. $\mathrm{T}_{\mathrm{FH}}$ were higher (in both absolute number and percentage) in Group I than in Group II CVID patients and normal controls (N). Within CXCR5+CD4+ T cells, the percentage of PD-1 (+) was higher and that of CCR7 (+) was lower in Group I than in Group II and N. The percentages of Treg and $\mathrm{T}_{\mathrm{FH}}$ reg were similar in both CVID groups and in $\mathrm{N}$. $\mathrm{T}_{\mathrm{FH}}$ responded to stimulation increasing the expression of the costimulatory molecules CD40L and ICOS as did N. After submitogenic PHA+IL-2 stimulation, intracellular expression of $\mathrm{T}_{\mathrm{FH}}$ cytokines (IL-10, IL-21) was higher than N in Group I, and IL-4 was higher than N in Group II. These results suggest that $\mathrm{T}_{\mathrm{FH}}$ are functional in CVID and highlight the association of increased circulating $\mathrm{T}_{\mathrm{FH}}$ with $\mathrm{AI}$ and GD manifestations.
\end{abstract}

\section{Introduction}

Common variable immunodeficiency (CVID) comprises a heterogeneous group of diseases characterized by abnormal antibody production [1]. It is the most commonly diagnosed primary immunodeficiency, with an incidence of $1 / 10000$ to $1 / 50000$. It affects both sexes equally and the clinical manifestations may begin at any age [2-4]. Over $90 \%$ of the patients present with recurrent acute and sometimes chronic bacterial infections mainly of the respiratory and gastrointestinal tracts. Another feature of these patients is their major susceptibility for autoimmunity (AI) manifestations, granulomatous diseases (GD), and cancer [5-10]. Diagnosis of CVID is based on a significant decrease of IgG (at least two standard deviations below the mean for age) associated with a decrease of IgA and/or IgM isotypes, in patients older than 4 years of age and absence of isohemagglutinins and/or poor response to polysaccharide vaccines, with other defined causes of hypogammaglobulinemia excluded $[2-4,11]$.

In most cases the etiology of CVID is not known. In a small percentage of patients, most families stranded, a few genetic defects have been described. These include mutations in genes coding for the inducible costimulator (ICOS) [12], CD19 [13, 14], CD20 [15], CD8 [16], and the B cell-activating factor receptor (BAFF-R) [17]. Eight to $10 \%$ of the patients carry mutations in the gene for the $\mathrm{B}$ cell receptor transmembrane activator and calcium-modulating cyclophilin ligand interactor (TACI). Similar mutations are found in unaffected relatives and normal controls, suggesting association but not causality [10, 18-23].

The process of acquiring an adequate antibody immune response is complex and involves specialized groups of $\mathrm{T}$ lymphocytes that interact with B lymphocytes in a tightly regulated way in the secondary lymphoid organs. This ultimately results in the generation of different immunoglobulin isotypes, memory effector, and regulatory cells. Failure at any of the stages of the process may lead to humoral immunodeficiency.

$\mathrm{T}$ follicular helper cells $\left(\mathrm{T}_{\mathrm{FH}}\right)$ have a central role in the generation of the germinal center reaction (GC) which is necessary for the correct maturation of the humoral immune 
response. Their absence or functional impairment generates defects in the assembly of B cell memory that lead to hypogammaglobulinemia. Most studies concerning the role of this $\mathrm{T}$ helper subset have been done in animal models, but in humans there is evidence that a group of CD4+ T lymphocytes characterized by the presence of the chemokine receptor CXCR5 reflects $\mathrm{T}_{\mathrm{FH}}$ present at the lymph nodes [24-26]. Programmed-death 1 (PD-1) is highly expressed in germinal center $\mathrm{T}_{\mathrm{FH}}$ and its expression is induced after activation in CD4 and CD8 cells [27-29]. The inhibitory role of the PD-1/PD-ligand (PDL-1 or PDL-2) axis has been defined in relation to the $\mathrm{T}$ cell mediated response to antigens, but its role in the regulation of the $\mathrm{B}$ cell responses is less clear. While some studies report attenuated antibody responses where the PD-1/PDL-1 and PDL-2 interactions are prevented [30], others observed heightened immune responses in coincidence with increased $\mathrm{T}_{\mathrm{FH}}$ numbers [31].

Circulating $\mathrm{T}_{\mathrm{FH}}$ are phenotypically and functionally heterogeneous. A subgroup of $\mathrm{T}_{\mathrm{FH}}$ with central memory/resting profile expressing chemokine receptor 7 (CCR7) predominates in normal individuals, while in patients with autoimmune conditions, $\mathrm{T}_{\mathrm{FH}}$ with high expression of programmeddeath 1 (PD-1) and low CCR7 are more abundant [32]. In addition, a subgroup of $\mathrm{T}_{\mathrm{FH}}$ expressing both CXCR5 and FoxP3 $\left(\mathrm{T}_{\mathrm{FH}}\right.$ reg) that may suppress $\mathrm{T}_{\mathrm{FH}}$ activity has been described [33]. Antibody deficiency and immune dysregulation in CVID could be related to absence or inefficient function of $\mathrm{T}_{\mathrm{FH}}$, to increased $\mathrm{T}_{\mathrm{FH}}$ reg action leading to downregulation of $\mathrm{T} / \mathrm{B}$ cell cooperation for the synthesis of antibodies, or to interference with $\mathrm{T}_{\mathrm{FH}}$ action due to other regulatory lymphocytes as CD8+ regulatory cells [34]. Based on these observations we decided to study the characteristics and function of $\mathrm{T}_{\mathrm{FH}}$ in peripheral blood of adult CVID patients divided into two clinical phenotypes according to the presence or absence of autoimmunity (AI) and/or granulomatous disease (GD).

\section{Material and Methods}

2.1. Subjects. We reviewed the clinical and epidemiological data of our cohort of twenty-one adult patients with CVID. The diagnosis of CVID was made according to standard criteria [2,3], and all subjects were on monthly immunoglobulin replacement therapy. Based on patients' clinical records, we analyzed the age at onset of infectious symptoms, age at diagnosis, age at the time of the study, length of followup from CVID diagnosis to time of the study, and clinical manifestations. Patients were divided into two categories: Group I $(n=8)$, patients with AI, GD, or both, and Group II $(n=13)$, patients without these clinical manifestations.

Blood samples were drawn before the infusion of immunoglobulin. All studies were performed blinded to the clinical manifestations of the immunodeficiency. Controls $(n=19)$ were age related normal blood donors $(\mathrm{N})$. This study was approved by the Ethics Committee of Academia Nacional de Medicina. All donors gave informed consent.
2.2. PBMC Isolation and Culture. Peripheral blood samples from all subjects were collected on heparin. PBMC were obtained by Ficoll-Hypaque (FH) centrifugation and suspended to $1 \times 10^{6} / \mathrm{mL}$ in RPMI tissue culture medium containing $10 \%$ fetal calf serum (GIBCO, Grand Island, USA), streptomycin, and penicillin (RPMI-FCS). PBMC cultures were carried out in round bottom $5 \mathrm{~mL}$ polystyrene tubes (Falcon) containing $2 \times 10^{6} \mathrm{PBMC}$ that were suspended in 2 mL RPMI-FCS [35].

\subsection{Cell Surface Phenotype of Mononuclear Cells from CVID} Patients and $N$ Controls. For assay of the different types of lymphocytes, flow cytometry techniques with a three-color assay were used. Aliquots of $100 \mu \mathrm{L}$ heparinized peripheral blood were incubated with monoclonal antibodies and then were lysed using FACS Lysing solution (Becton Dickinson, San Jose, CA, USA) following the manufacturer's instructions. Analysis of surface markers was performed on a FACScan cytometer (Becton Dickinson, San Jose, CA, USA) and analyzed with FCS Express software. Lymphocytes were selected according to size (FSC) and side (SSC) scatter profiles. PBMC were also processed both before and after cell culture. Fluorescein isothiocyanate (FITC), phycoerythrin (PE), Alexa 488, or peridinin chlorophyll protein (PerCP) antihuman labelled monoclonal antibodies were used according to the manufacturers' instructions. Anti-CD4 (clone RPAT4), CD25 (clone M-A251), CD45RO (clone UCHL1), CXCchemokine receptors, 5 (CXCR5) (CD185, clone RF8B2) and 7 (CCR7, Clone 3D12), CD19 (clone HIB19), CD27 (clone M-T271), inducible $\mathrm{T}$ cell costimulator (ICOS) (CD278, clone DX29), CD40 ligand (CD40L) (CD154, clone TRAP1), and programmed-death 1 (PD-1) (CD279, clone MIH4) antibodies were purchased from BD Pharmingen, BD, and eBioscience (San Diego, CA, USA). Absolute numbers of the different lymphocytes were calculated taking into account the white cell count and the percentage of lymphocytes in MayGrünwald-Giemsa stained blood smears.

The phenotype of viable PBMC from CVID and N donors was analyzed before and after 2 or 7 days of PHA+IL-2 stimulated culture (performed as detailed below for the assay of cytokines). Lymphocyte viability was calculated taking into account the proportion of live lymphocytes in the SSC/FSC dot plots. Appropriate isotype controls were used to define the positive populations.

2.4. FoxP3+CD25+ T Cells (Treg) and FoxP3+CXCR5+ T Cells $\left(T_{F H}\right.$ reg). For Treg and $\mathrm{T}_{\mathrm{FH}}$ reg determination, $\mathrm{PBMC}$ were stained with PerCP anti-CD4 and FITC anti-CD25 or PerCP anti-CD4 and Alexa 488 anti-CXCR5. Then they were fixed and permeabilized with Fix and Perm (Caltag Laboratories, Burlingame, California, USA) according to the manufacturer's instructions. After permeabilization they were reacted with PE anti-FoxP3 (clone PCH101, eBioScience, San Diego, CA, USA).

2.5. Costimulatory Molecules (CD40L and ICOS) and Intracellular Il-10, IL-21, and IL-4 in CVID and N. PBMC 
TABLE 1: Clinical and epidemiological data of Group I patients.

\begin{tabular}{|c|c|c|c|c|c|c|c|}
\hline Patient & Sex & Age (years) & $\begin{array}{c}\text { Age at onset } \\
\text { (years) }\end{array}$ & $\begin{array}{l}\text { Age at Dx. } \\
\text { (years) }\end{array}$ & $\begin{array}{c}\text { Follow up D. } \\
\text { (years) }\end{array}$ & GD & AI \\
\hline 1 & $\mathrm{~F}$ & 65 & 31 & 41 & 24 & Larynx, bowel, conjuntiva, skin & Hypothyroidism \\
\hline 2 & M & 36 & 1 & 13 & 23 & LIP, LN & AHA \\
\hline 3 & $\mathrm{~F}$ & 21 & 16 & 17 & 4 & 0 & ITP, AHA \\
\hline 4 & M & 69 & 50 & 66 & 3 & Lung, bowel & ITP \\
\hline 5 & $\mathrm{~F}$ & 69 & ND & 66 & 3 & LIP & 0 \\
\hline 6 & $\mathrm{~F}$ & 36 & ND & 20 & 16 & 0 & E N \\
\hline 7 & M & 30 & ND & 14 & 16 & Lung, LN & ALOP \\
\hline 8 & $\mathrm{~F}$ & 59 & 25 & 43 & 16 & 0 & AHA, N \\
\hline
\end{tabular}

LN: lymph node; LIP: Lymphocytic interstitial pneumonia. LIP diagnoses were made by pathological examination in patients \#1, \#2 and \#7. LIP in patient \#4 was established by CAT scan. AHA: autoimmune hemolytic anemia; ALOP: alopecia aereata; ITP: immune thrombocytopenia; EN: erythema nodosum, N: autoimmune neutropenia.

$\left(10^{6} / \mathrm{mL}\right)$ were stimulated with $2.5 \mu \mathrm{g} / \mathrm{mL}$ phytohemagglutinin (PHA-P, Sigma, L1668, St. Louis, MO, USA) and 5 UI/mL interleukin-2 (IL-2, Peprotech, New Jersey, USA) and cultured at $37^{\circ} \mathrm{C}$ in the $\mathrm{CO}_{2}$ incubator for 2 days for costimulatory molecules and for 7 days for intracellular cytokines. The time and concentration of PHA and IL-2 were selected on the basis of previous studies [36]. IL-2 was replenished after 5 days of culture. Controls consisted of PBMC cultures performed in the absence of PHA and IL-2. For costimulatory molecules, $\mathrm{PBMC}$ were stained with PerCP anti-CD4, Alexa 488 anti-CXCR5, and either PE anti-CD40L or PE anti-ICOS. For intracellular cytokines, twelve hours before harvesting the cell pellets, these were resuspended in RPMI-FCS $\left(10^{6} / \mathrm{mL}\right)$ and $10 \mu \mathrm{L}$ of $2 \mu \mathrm{M}$ monensin solution (BD Pharmingen, San Diego, CA, USA) was added to the cell suspensions. After washing, the cells were stained with CD4, CXCR5 monoclonal antibodies for 20 minutes at room temperature and then fixed and permeabilized with the Fix and Perm (Caltag Laboratories, Burlingame, California, USA). Cells were finally stained with anti-IL-10 (clone JES39D7), anti-IL-21 (clone 3A3-N2.1), or anti-IL-4 (clone 8D4-8) antibodies (BD Pharmingen, San Diego, CA, USA) and the appropriate isotype controls for 45 minutes at $4^{\circ} \mathrm{C}$, washed again, and the percentage of intracellular IL-10+, IL-21+, or IL-4+ CD4+ lymphocytes as well as that of CD4 lymphocytes that coexpressed CXCR5 and IL-10+, IL-21+, or IL-4+ was determined.

2.6. Statistical Analysis. Graphical presentation and statistical analysis of the data were performed using GraphPad Prism 4.0 (GraphPad Software, San Diego, CA, USA). Comparisons between groups were analyzed by a one-way ANOVA and a nonparametric Mann-Whitney test. Correlations between samples were calculated using the linear regression model. $P$ values of less than 0.05 were considered significant.

\section{Results}

3.1. CVID Patients. We analyzed data on 11 male and 10 female CVID patients; the mean age of patients at the time of the study was $49.9 \pm 15.8$ years (range 21 to 73 ), median 38.5. The age at onset of disease was available for 15 patients, one patient did not have infections, and mean age was $19.4 \pm$ 15.2 years (range 1 to 50 ), median 19. Mean age at diagnosis was $35.4 \pm 18.2$ years (range 13 to 70 ), median was 31.5 years, and mean follow-up duration was $10.6 \pm 7.8$ years (range 1 to 24 ), median 10.5. All patients were on gammaglobulin replacement therapy since diagnosis.

Patients were divided into two categories, Group I, eight patients, and Group II, 13. The clinical and epidemiological data of Group I patients are shown in Table 1. Patients 4 and 5 had AI disease manifestations 13 and 33 years, respectively, before the onset of infectious symptoms. With the exception of patient 1 that was studied under steroid and infliximab treatment [37], none of the patients in Group I received systemic steroids, standard immunosuppressive therapies, or biologic agents at the time of the study.

3.2. Absolute Values of T and B Lymphocytes in CVID and N. The total number of lymphocytes, $\mathrm{CD} 4+\mathrm{T}$ cells, and $\mathrm{T}_{\mathrm{FH}}$ cells (CXCR5+CD4+) was measured in peripheral blood from CVID patients, right before iv immunoglobulin replacement. As shown in Figure 1, the number of CD4+ lymphocytes was not significantly different in both CVID groups compared to $\mathrm{N}$, but $\mathrm{T}_{\mathrm{FH}}$ cells were elevated, especially in Group I patients (Figure 1(a)).

In Group I patients the absolute number of CD19+ cells correlated with that of $\mathrm{T}_{\mathrm{FH}}$ cells suggesting a link in the regulation of these two cell populations (Figure 1(b)). There was no significant correlation between CD19+ cells and $\mathrm{T}_{\mathrm{FH}}$ in Group II and N. A similar analysis was performed between the absolute number of CD27+CD19+ and those of $\mathrm{T}_{\mathrm{FH}}$ cells. We found significant correlation only in Group I of patients.

In 2/8 Group I patients and in 6/13 of Group II patients, the percentage of CD19+ B lymphocytes (1.6 to $4.71 \%$ ) was below normal (N\% CD19+, mean + SD: $9.93+3.21, n=15)$.

3.3. Follicular $T$ Lymphocytes $\left(T_{F H}\right), T_{F H}$ Subpopulations, Treg, and $T_{F H}$ reg in CVID and $N$. Because CD4 lymphocytes provide essential help for the maturation of $\mathrm{B}$ cell memory, we further analyzed the expression of markers associated 


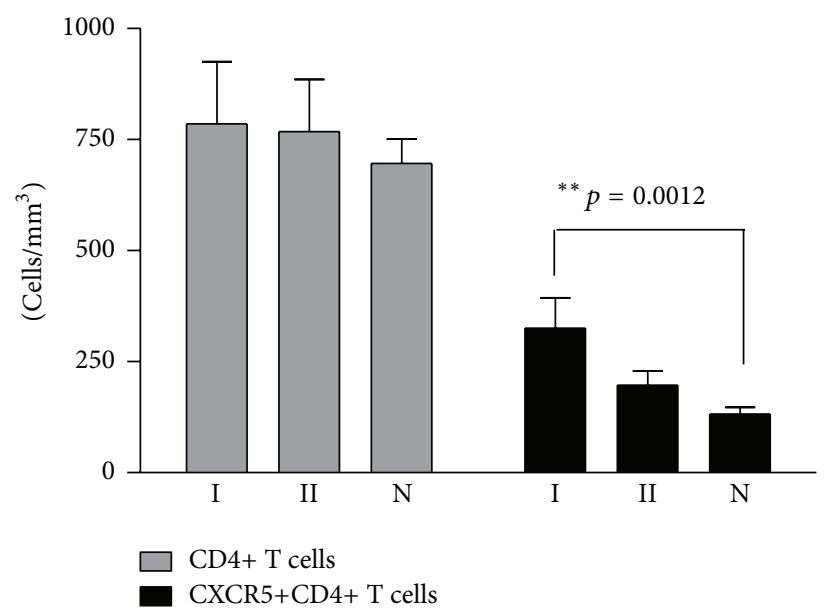

(a)
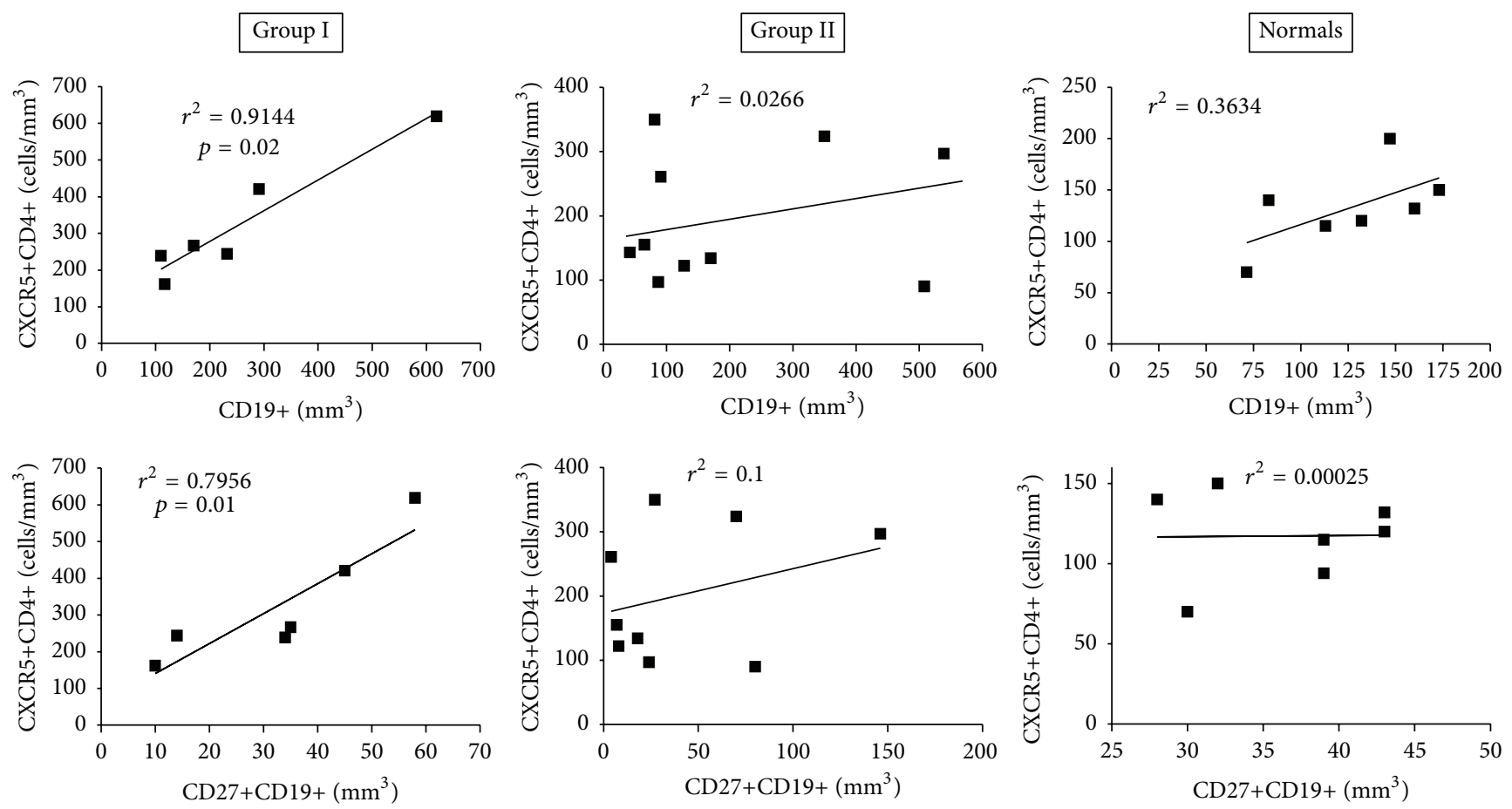

(b)

FIGURE 1: $\mathrm{T}_{\mathrm{FH}}$ and B lymphocyte absolute values in CVID and N. (a) Absolute lymphocyte values (cells/ $\mathrm{mm}^{3}$ ) were calculated in CVID Group I, $n=8$ (I), and Group II, $n=13$ (II), patients and control donors (N), $n=19$. Peripheral blood was stained with monoclonal antibodies and absolute values of viable CD4+ T lymphocytes and CD4+ T cells coexpressing CXCR5 $\left(\mathrm{T}_{\mathrm{FH}}\right)$ were calculated after analysis on a FACScan Becton Dickinson flow cytometer. (b) A comparison between peripheral blood viable B lymphocytes (CD19+ cells), memory B lymphocytes $\left(\mathrm{CD} 27+\mathrm{CD} 19+\right.$ cells), and $\mathrm{T}_{\mathrm{FH}}$ values (CXCR5+CD4+ cells) was done in CVID Group I, Group II, and N controls. Lineal regression analysis was consigned in the graphs. Only in Group I was the correlation statistically significant.

with follicular helper T cells (CXCR5 and PD-1) in CD4 lymphocytes. The results shown in Figure 2 demonstrate that the percentage of CXCR5+CD4+ T cells was higher in Group I CVID patients when compared to those of Group II and N. Regarding Group II CVID patients, there were no significant differences when compared to $\mathrm{N}$. Concerning coexpression of PD-1 and CXCR5, the highest values were observed in CVID patients with a GD and/or AI disease phenotype (Group I).
In some patients the studies could be repeated after 1224 months and the CXCR5+PD-1+ percentages in the CD4 region remained high (patient \#CM initial value: 23.28\%; after 24 months: $25.91 \%$; after 26 months: $25.32 \%$; patient \#PV initial value: $15.5 \%$; after 12 months: $18.39 \%$; after 14 months: $16.38 \%)$.

Because low CCR7 and high PD-1 expression have been observed in circulating $\mathrm{T}_{\mathrm{FH}}$ from patients with autoimmune 


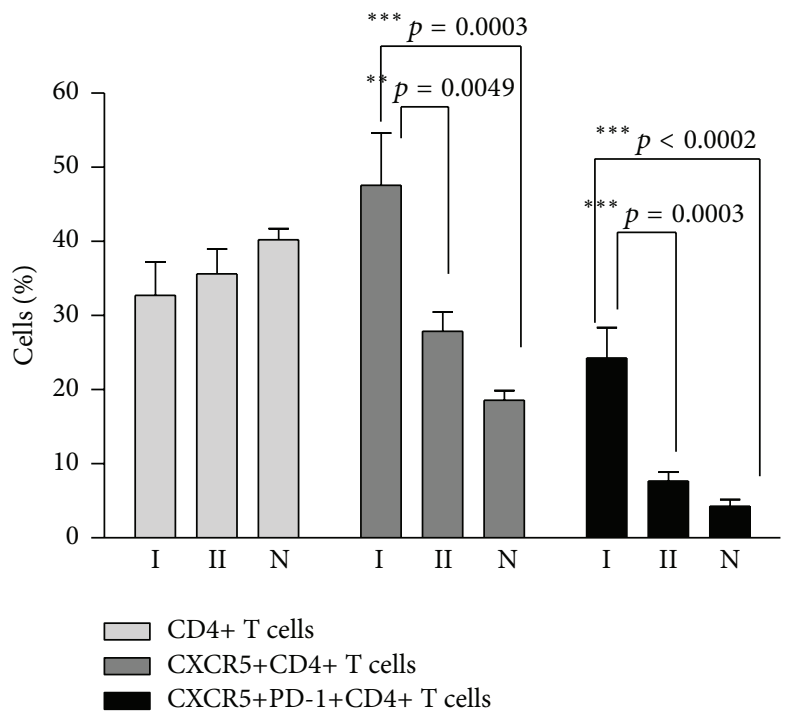

(a)
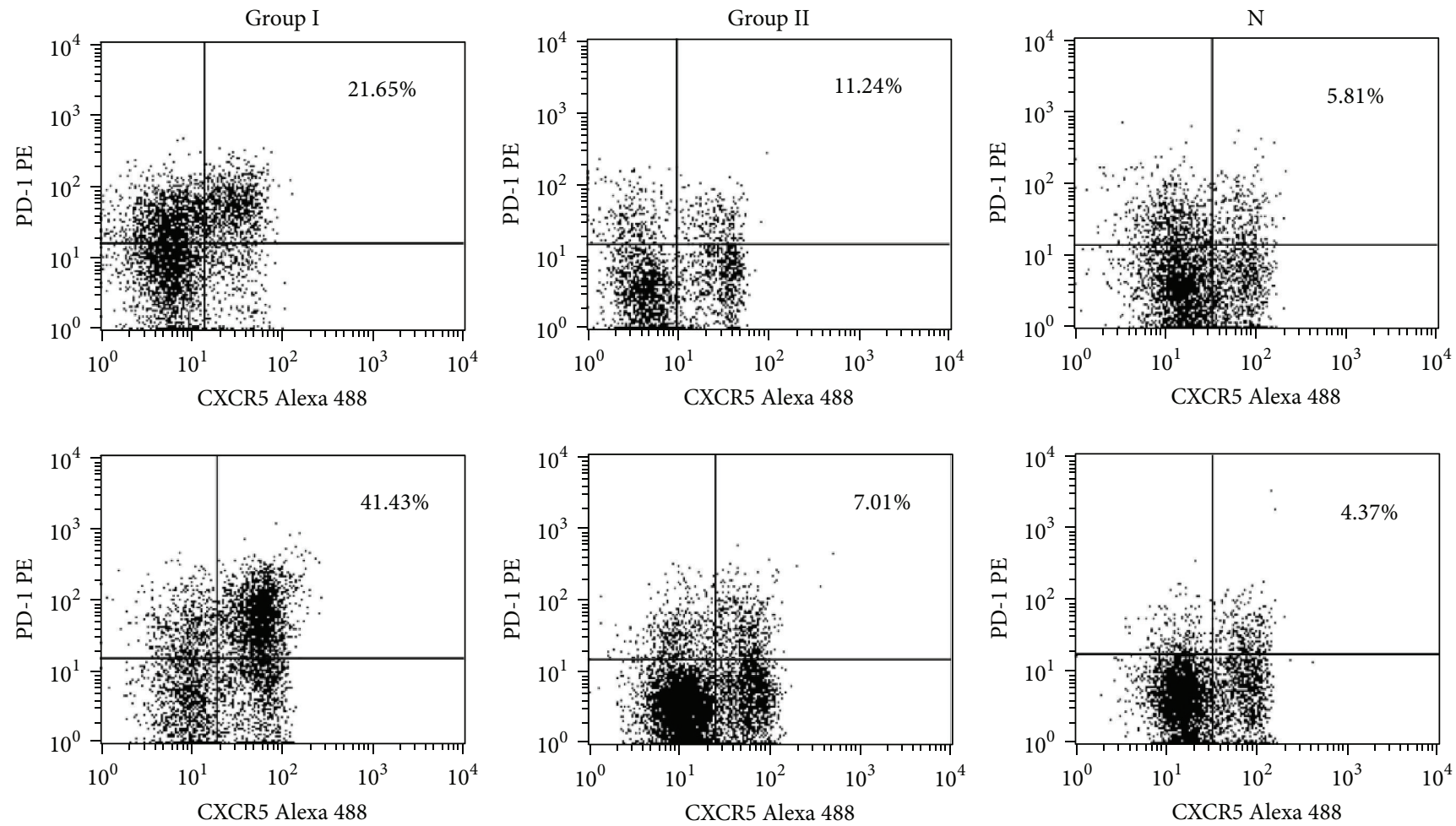

(b)

Figure 2: Percentage of $\mathrm{T}_{\mathrm{FH}}$ (CXCR5+CD4+ T cells) and of $\mathrm{T}_{\mathrm{FH}}$ coexpressing PD-1 in CVID and N. (a) The percentage of CD4+ T cells and CD4+ T coexpressing CXCR5 or CXCR5+PD-1+ was assayed for CVID patient Groups I $(n=7)$ and II $(n=10)$ and N $(n=12)$. Statistical differences are consigned in the graph. (b) An example of cytometry analysis of two different Group I and Group II CVID patients and two different $\mathrm{N}$ controls.

conditions, we examined the $\mathrm{T}_{\mathrm{FH}}$ subsets considering the level of expression of these molecules on the surface of CXCR5+CD4+ T cells from CVID patients and $\mathrm{N}$ controls. The results shown in Figure 3 demonstrate that high PD-1 and low CCR7 expression were the rule in Group I compared to
Group II and N. PD-1 was also higher than N in Group II but CCR7 values did not differ from those of $\mathrm{N}$.

The percentages of Treg (CD25+ Foxp3+/CD4) and $\mathrm{T}_{\mathrm{FH}}$ reg (CXCR5+ Foxp3+/CD4) within the CD4+ T lymphocyte region were similar in both CVID groups and in $\mathrm{N}$ (mean \pm 


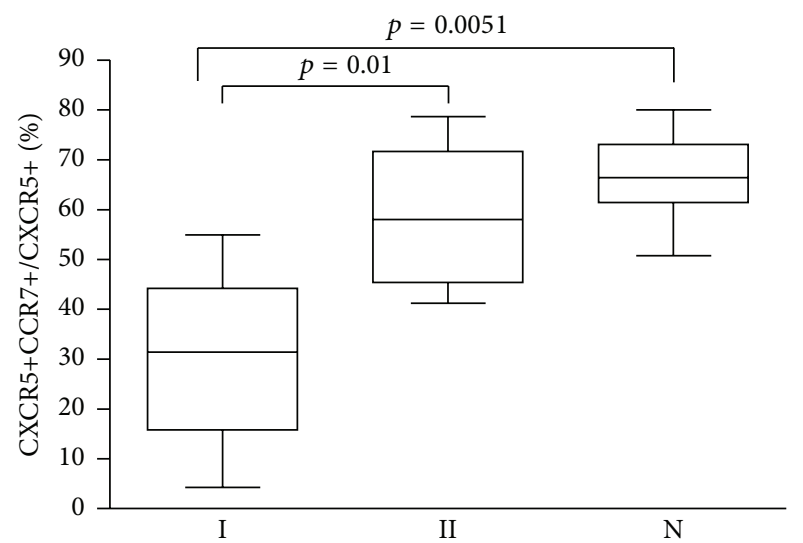

(a)

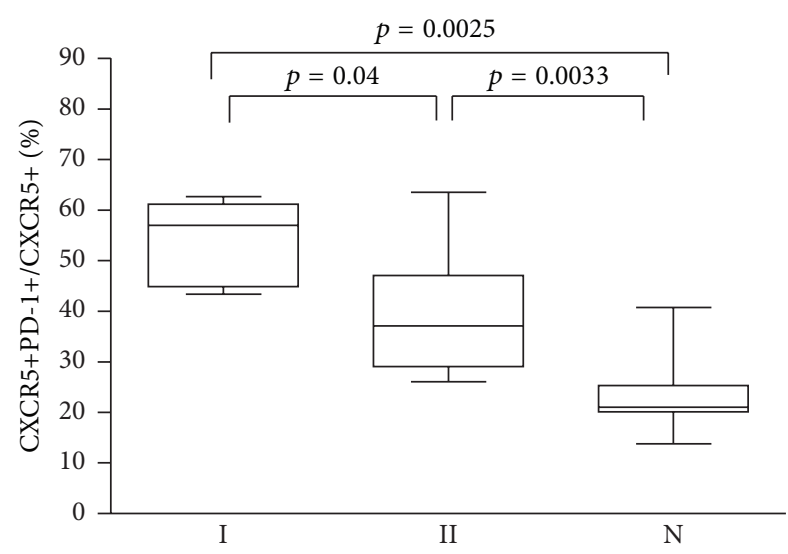

(b)

FIGURE 3: CCR7 and PD-1 expression in $\mathrm{T}_{\mathrm{FH}}$ of CVID patients. The percentage of CCR7+ cells within the CXCR5+CD4+ T lymphocyte region was calculated for CVID Group I and Group II patients and N (\% CXCR5+CCR7+/CXCR5+) (a). Likewise, the percentage of PD-1+ cells in the CXCR5+CD4+ T lymphocyte region was determined (CXCR5+PD-1+/CXCR5+) (b). Statistical differences are consigned in the graph.

SD, Group I, Treg: $4.42 \pm 1.61 \%, \mathrm{~T}_{\mathrm{FH}}$ reg: $3.54 \pm 1.38 \%$; Group II, Treg: $4.88 \pm 4.61 \%, \mathrm{~T}_{\mathrm{FH}}$ reg: $3.21 \pm 2.87 \%$; $\mathrm{N}$, Treg: $4.00 \pm$ $2.16 \%, \mathrm{~T}_{\mathrm{FH}}$ reg: $\left.2.30 \pm 1.83 \%\right)$.

3.4. Upregulation of Costimulatory Molecules CD40L and ICOS in CVID and N. Defects in the expression of costimulatory molecules on CD4 lymphocytes could underlie the lack of an adequate humoral response. Therefore we examined CD40L and ICOS expression on CD4 T lymphocytes and CXCR5+CD4+ T lymphocytes after 2 days of culture either nonstimulated (medium) or with PHA+IL-2 stimulation (PHA+IL-2). After T cell stimulation, expression of both CD40L and ICOS could be induced in CD4 cells and in CXCR5+CD4+ T lymphocytes from CVID patients to a similar extent to $\mathrm{N}$ (Table 2 ).

\subsection{IL-10, IL-21, and IL-4 Induction by T Cell Stimuli in CVID} and $N$. Although other subtypes of T helper lymphocytes can synthesize these cytokines, human $\mathrm{T}_{\mathrm{FH}}$ produce abundant IL21 and IL-10 upon stimulation. IL-4 is also a CD4-derived cytokine involved in the process of antibody generation and it can be produced by Th2 CD 4 lymphocytes and by the Th2 subset of $\mathrm{T}_{\mathrm{FH}}$ [24]. In order to assess the ability of CD4 T cells to produce these cytokines, PBMC were stimulated with a submitogenic dose of PHA and IL-2. The percentage of CD4 T cells with intracellular IL-10, IL-21, or IL-4 was recorded. The percentage of IL-10+ and IL-21+ CD4+ T cells was higher than $\mathrm{N}$ in CVID Group I and Group II after PHA stimulation while IL-4+ CD4+ $\mathrm{T}$ cells were not different to $\mathrm{N}$ in both CVID groups. When considering cytokine (IL-10, IL-21, and IL-4) expression by CD4+CXCR5+ T cells $\left(\mathrm{T}_{\mathrm{FH}}\right)$, it was similar in both groups of CVID to that of N. However, when cytokine expression (IL-10 and IL-21) was analyzed in CD4+ T cells that did not express CXCR5, it was significantly higher $(p<$ 0.029 ) in both CVID groups than in N (Figures 4(a) and 4(b)). IL-4 expression was higher than $\mathrm{N}(p=0.036)$ in CXCR5CD4+ T cells (Figure 4(c)) in Group II patients.

\section{Discussion}

It is difficult to determine the immunopathogenic importance and/or predictive value of different laboratory findings in relation to clinical manifestations in adult CVID. Attempts to correlate clinical observations with laboratory data has led to different classifications that take into account serum immunoglobulin levels, flow cytometry characteristics of CVID B lymphocytes, or B lymphocyte function [38]. Phenotyping of $\mathrm{B}$ cell subpopulations has confirmed the reduction of switched memory B cells (IgM-IgD-CD27+CD19+) in association with splenomegaly or granulomatous disease [38]. Changes in the proportion of other subgroups of $B$ lymphocytes have also been described in CVID [39-41].

We have now studied a series of adult CVID patients, trying to correlate clinical findings with some characteristics of the peripheral blood T lymphocyte phenotype. Patients were divided in two groups: those who had evidence of AI disease or GD (Group I) and those who did not (Group II).

Because $\mathrm{T}_{\mathrm{FH}}$ are important for the setup of a correct antibody response, we have focused on this helper $\mathrm{T}$ cell subpopulation in relation to the occurrence of immune dysregulation associated with GD or AI disease. Interestingly, we observed that the number of CXCR5+CD4+ T cells was significantly related to the number of CD19+ B lymphocytes, in Group I patients (with a similar tendency in N), suggesting that there may be a link in the regulation of the number of these lymphocytes.

Our results clearly show that the $\mathrm{T}_{\mathrm{FH}}$ population was expanded in both groups of CVID patients, but CXCR5 and PD-1 coexpression was higher in Group I than in Group II and N. PD-1 is a potent inhibitory receptor important for $\mathrm{T}$ cell tolerance and it has been associated with CD8 $\mathrm{T}$ cell exhaustion during chronic viral infection [7, 28, 42]. A subgroup of $\mathrm{T}_{\mathrm{FH}}$ defined by high PD-1 and low CCR7 expression has been demonstrated in patients with autoimmune conditions [32]. These cells seem to be the counterpart of active effector CD4 T cells within the $\mathrm{T}_{\mathrm{FH}}$ compartment 
TABLE 2: Expression of costimulatory molecules (CD40L and ICOS) in PHA+IL-2 stimulated PBMC from CVID patients and N.

\begin{tabular}{|c|c|c|c|c|}
\hline & \multicolumn{4}{|c|}{ Costimulatory molecules expression in CD $4+$ lymphocytes $(\%$, mean $\pm \mathrm{SE})$} \\
\hline & $\mathrm{CD} 40 \mathrm{~L}+$ & CXCR5+CD40L+ & ICOS & CXCR5+ICOS+ \\
\hline \multicolumn{5}{|c|}{ Group I $(n=4)$} \\
\hline Medium & $1.8 \pm 2$ & $1.7 \pm 1.2$ & $3.0 \pm 0.2$ & $2.2 \pm 1.7$ \\
\hline PHA+IL-2 & $11.0 \pm 3.7$ & $9.4 \pm 3.5$ & $24.4 \pm 8.2$ & $17.0 \pm 5.3$ \\
\hline \multicolumn{5}{|c|}{ Group II $(n=4)$} \\
\hline Medium & $2.4 \pm 2$ & $1.9 \pm 1.1$ & $4.3 \pm 1.8$ & $3.0 \pm 1.7$ \\
\hline PHA+IL-2 & $11.5 \pm 4.1$ & $10.3 \pm 4.2$ & $22.8 \pm 9.0$ & $15.6 \pm 6.5$ \\
\hline \multicolumn{5}{|c|}{ Normals $(n=7)$} \\
\hline Medium & $2.3 \pm 1.5$ & $2.0 \pm 1.3$ & $2.8 \pm 3.2$ & $1.8 \pm 0.9$ \\
\hline PHA+IL-2 & $7.3 \pm 1.5$ & $6.4 \pm 1.5$ & $16.3 \pm 1.8$ & $7.2 \pm 1.1$ \\
\hline
\end{tabular}

PBMC were stimulated with $2.5 \mu \mathrm{g} / \mathrm{mL}$ phytohemmagglutinin and $5 \mathrm{UI} / \mathrm{mL}$ interleukin- 2 for 2 days and then were stained with anti-CD4, anti-CXCR5 and either anti-CD40L or anti-ICOS. The percentage of CD4+ cells that express CD40L, CXCR5 plus CD40L, ICOS and CXCR5 plus ICOS is consigned. No significant differences were observed between both CVID groups and Normals.

and contrast with central memory/resting $\mathrm{T}_{\mathrm{FH}}$ having high CCR7 expression and lower PD-1 that are present in higher numbers in $\mathrm{N}$. In our series, $\mathrm{T}_{\mathrm{FH}}$ exhibiting high PD-1 and low CCR7 were also more prominent in Group I than in Group II and $\mathrm{N}$. Nevertheless, it is interesting to note that $\mathrm{T}_{\mathrm{FH}}$ from Group II patients without AI or GD had also lower CCR7 and higher PD-1 expression than N. Long term follow-up of these patients may give an insight into the relationship of $\mathrm{T}_{\mathrm{FH}}$ and development of AI or GD in CVID.

Recently, the regulatory role of $\mathrm{T}_{\mathrm{FH}}$ lymphocytes bearing the Treg transcription factor FoxP3 and CXCR5 $\left(\mathrm{T}_{\mathrm{FH}}\right.$ reg) in the generation of humoral immunity has been emphasized [43]. It was found that PD-1/PD-ligand 1 (PDL-1) interactions affected the outcome of T/B cooperation. PD-1 deficient mice had more $\mathrm{T}_{\mathrm{FH}}$ reg than wild type mice and these $\mathrm{PD}$ 1 deficient $\mathrm{T}_{\mathrm{FH}}$ reg had enhanced ability to suppress $\mathrm{T}_{\mathrm{FH}}$ function [43]. Apparently, overexpression of FoxP3 + CD4+ T cells (either Treg or $\mathrm{T}_{\mathrm{FH}}$ reg) was not the case in CVID, since neither Treg nor $\mathrm{T}_{\mathrm{FH}}$ reg values differed from those of $\mathrm{N}$ in both CVID groups.

In addition to detailed studies on B lymphocyte phenotype and differentiation in CVID patients, the function of both $\mathrm{CD} 4+$ and $\mathrm{CD} 8+\mathrm{T}$ lymphocytes has been thoroughly studied in CVID. A defect in the integration of activating signals derived from the TCR and costimulatory molecules in CD4 and CD8 T lymphocytes in CVID patients was demonstrated [44]. Furthermore, it was shown that the proliferative response of purified CD4 and CD8 T lymphocytes to recall antigens and superantigens was impaired due to a defect in the early phase of $\mathrm{T}$ cell receptor-mediated $\mathrm{T}$ cell activation [45]. Antigen presentation by CVID monocytes or B lymphocytes was unaffected in CVID [46]. Our studies have been focused on the action of a nonmitogenic dose of PHA on $\mathrm{T}_{\mathrm{FH}}$ in culture. There are important differences in this experimental procedure and the ones reported before. We did not evaluate the proliferative response of PBMC and we did not work with purified cell populations (CD4 or CD8) as did the previous studies. In spite of their increased numbers, the function of $\mathrm{T}_{\mathrm{FH}}$ could have been impaired in CVID. Our results demonstrate that $\mathrm{T}_{\mathrm{FH}}$ cells (in the presence of the monocytes and B lymphocytes that coexist in PBMC) are able to upregulate the costimulatory molecules CD40L and ICOS and can respond in vitro by producing the cytokines involved in T-B cooperation to the same extent in Group I and Group II patients as in N. This does not imply that upon physiologic TCR stimulation this will be occurring in vivo. Intracellular synthesis of IL-10 and IL-21 (cytokine markers of $\mathrm{T}_{\mathrm{FH}}$ cells) as well as that of IL-4 was similar to that of $\mathrm{N}$ in PHAstimulated CVID CD4+CXCR5+ T lymphocytes. Notably, intracellular expression of IL-10, IL-21, and IL-4 was also higher than $\mathrm{N}$ in PHA-stimulated CXCR5-negative CD4+ T cells from CVID patients. In this regard, an important role of IL-21 (either from $\mathrm{T}_{\mathrm{FH}}$ or from other cell sources) as a player in the differentiation of Th17 cells that are important in autoimmunity has been recently proposed [47]. It is possible that an IL-21-stimulated Th17 response could play a role in the generation of AI or EG in CVID patients. Because $\mathrm{T}_{\mathrm{FH}}$ comprise a heterogeneous group of cells, increased circulating CXCR5+CD4+ T lymphocytes might not reflect their ability to cooperate with antibody production. $\mathrm{T}_{\mathrm{h} 2} \mathrm{~T}_{\mathrm{FH}}$ are required for adequate antibody synthesis, while $\mathrm{T}_{\mathrm{h} 1} \mathrm{~T}_{\mathrm{FH}}$ are not [24]. The fact that after stimulation with PHA CXCR5+CD4+ T cells from CVID patients produced IL- 4 in addition to IL-21 and IL-10 indicates that lack of $\mathrm{T}_{\mathrm{h} 2} \mathrm{~T}_{\mathrm{FH}}$ was not the cause of the immunologic defect in this case.

High $\mathrm{T}_{\mathrm{FH}}$ in circulation has also been reported in some autoimmune conditions [48] and this is interesting in relation to the increased occurrence of autoimmune phenomena in CVID. Indeed, in juvenile dermatomyositis (JDM), immune dysregulation leads to skewing of blood CXCR5 $+\mathrm{T}_{\mathrm{h}}\left(\mathrm{T}_{\mathrm{FH}}\right)$ subsets towards $\mathrm{T}_{\mathrm{h} 2}$ and $\mathrm{T}_{\mathrm{h} 17} \mathrm{~T}_{\mathrm{FH}}$ [24], while in JDM and other autoimmune conditions as systemic lupus erythematosus (SLE) or Sjogren's disease, increased levels of functional CXCR5+CD4+ T cells lead to hypergammaglobulinemia and autoantibody synthesis [49-51] in CVID hypogammaglobulinemia or selected immunoglobulin deficiency occurs, probably as a result of impaired B cell maturation [52]. On the other hand, repeated infections or continuous activation of the inflammatory response [53] could also determine the $\mathrm{T}_{\mathrm{FH}}$ increase, since circulating $\mathrm{T}_{\mathrm{FH}}$ with an active effector profile 


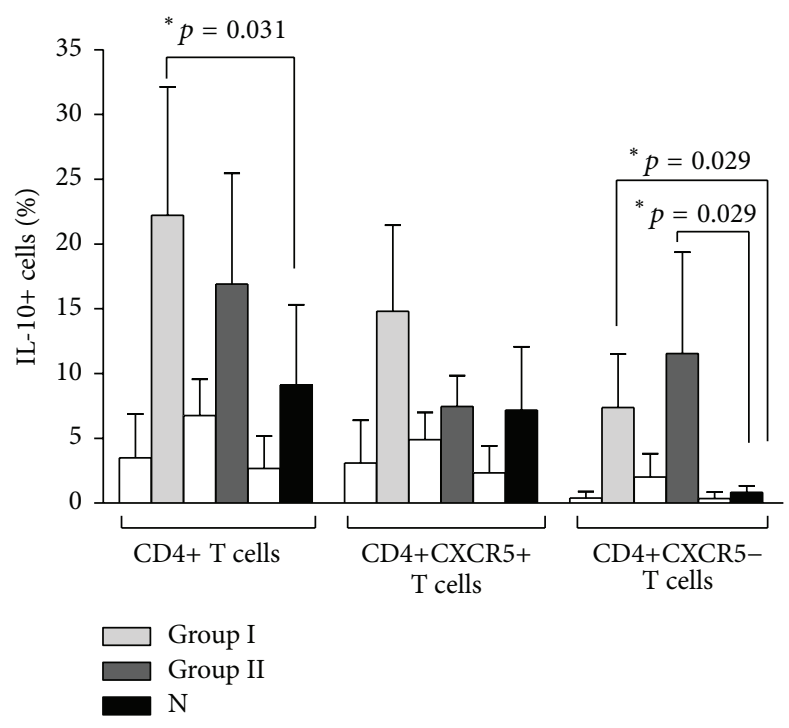

(a)

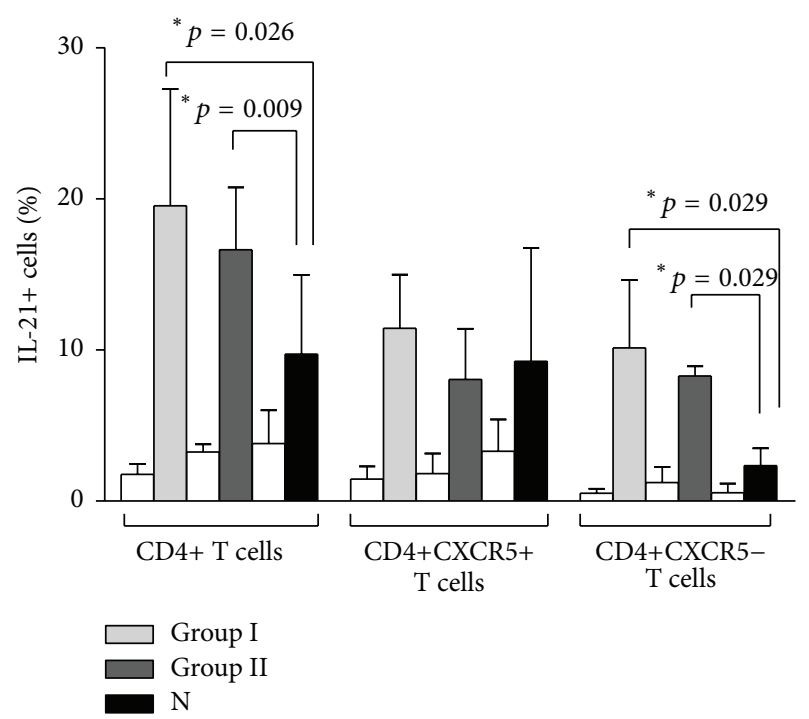

(b)

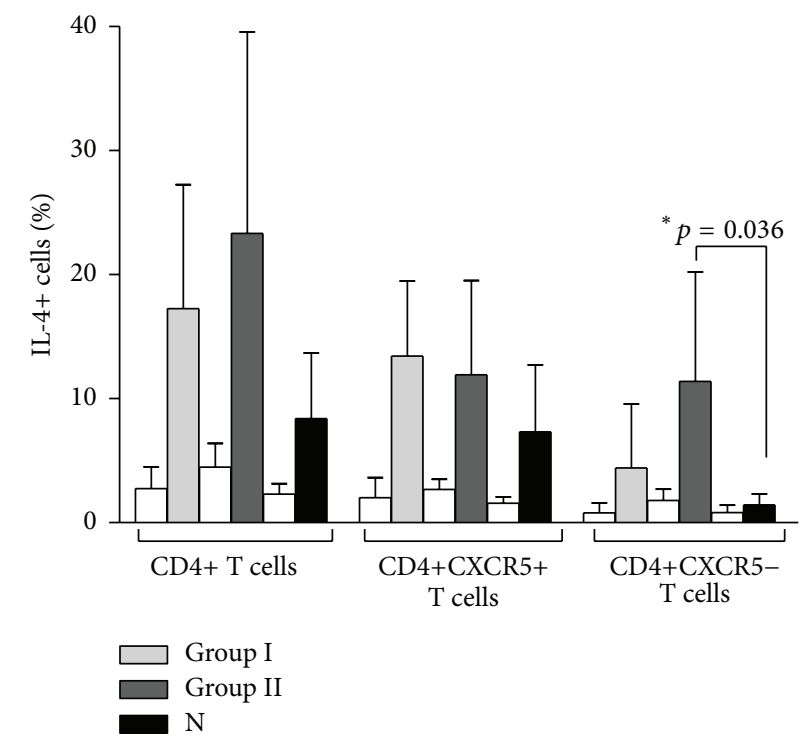

(c)

FIGURE 4: Intracellular cytokines after PHA+IL-2 stimulation of PBMC in CVID and N. The percentage of intracellular cytokines ((a) IL-10, (b) IL-21, and (c) IL-4) in permeabilized CD4+ T cells (CXCR5+ and CXCR5-) was determined after 7 days of PHA+IL-2 stimulation in CVID Group I $(n=4)$, Group II $(n=4)$, and $\mathrm{N}(n=6)$. Statistical differences are consigned in the graph. White bars represent unstimulated controls.

(high PD-1, low CCR7) were highest in patients with GD, AI, or both GD and AI manifestations.

\section{Conclusions}

Our results demonstrate that circulating $\mathrm{T}_{\mathrm{FH}}$ are higher than normal in adult CVID patients. $\mathrm{T}_{\mathrm{FH}}$ were able to respond to stimulation upregulating costimulatory molecules and providing the appropriate $\mathrm{B}$ helping cytokines. This suggests that intrinsic functional $\mathrm{T}_{\mathrm{FH}}$ defects are not the primary cause of CVID. Moreover, increased levels of circulating $\mathrm{T}_{\mathrm{FH}}$ highlight the relationship of CVID with other autoimmune diseases.

\section{Abbreviations \\ CVID: Common variable immune deficiency \\ $\mathrm{T}_{\mathrm{FH}}: \quad \mathrm{T}$ follicular helper cells \\ GD: Granulomatous disease \\ AI: Autoimmunity \\ ICOS: Inducible costimulator \\ $\mathrm{T}_{\mathrm{FH}}$ reg: Regulatory $\mathrm{T}$ follicular helper cells.}

\section{Competing Interests}

None of the authors has any potential financial competing interests related to this paper. 


\section{Authors' Contributions}

Ana Coraglia and Nora Galassi equally contributed to the paper. Ana Coraglia and Nora Galassi performed experiments and interpreted, analyzed, and wrote the paper; Marta Felippo performed experiments; Diego S. Fernández Romero, M. Cecilia Juri, and Alejandro Malbrán were in charge of diagnosis and assistance of the patients and discussed laboratory results; María M. E. de Bracco designed and directed the study and wrote the paper.

\section{Acknowledgments}

The authors acknowledge the assistance of Dr. N. Riera and M. Belen Irigoyen of the Cytometry Laboratory-IMEX. This work was supported by grants from ANPCYT-SECYT and CONICET PIP 11220100100032, Buenos Aires, Argentina, and by Fundacion Rene Baron, Buenos Aires, Argentina.

\section{References}

[1] M. E. Conley, L. D. Notarangelo, and A. Etzioni, "Diagnostic criteria for primary immunodeficiencies," Clinical Immunology, vol. 93, no. 3, pp. 190-197, 1999.

[2] International Union of Immunological Societies, "Primary immunodeficiency diseases report of an IUIS scientific committee," Clinical \& Experimental Immunology, vol. 118, supplement 1, pp. 1-28, 1999.

[3] F. A. Bonilla, I. L. Bernstein, D. A. Khan et al., "Practice parameter for the diagnosis and management of primary immunodeficiency," Annals of Allergy, Asthma \& Immunology, vol. 94, supplement 1, pp. S1-S63, 2005.

[4] A. A. Bousfiha, L. Jeddane, F. Ailal et al., "A phenotypic approach for IUIS PID classification and diagnosis: guidelines for clinicians at the bedside," Journal of Clinical Immunology, vol. 33, no. 6, pp. 1078-1087, 2013.

[5] R. A. Hermaszewski and A. D. Webster, "Primary hypogammaglobulinemia: a survey of clinical manifestations and complications," Quarterly Journal of Medicine, vol. 86, no. 1, pp. 31-42, 1993.

[6] C. Cunningham-Rundles and C. Bodian, "Common variable immunodeficiency: clinical and immunological features of 248 patients," Clinical Immunology, vol. 92, no. 1, pp. 34-48, 1999.

[7] I. Quinti, A. Soresina, G. Spadaro et al., "Long-term follow-up and outcome of a large cohort of patients with common variable immunodeficiency," Journal of Clinical Immunology, vol. 27, no. 3, pp. 308-316, 2007.

[8] E. Oksenhendler, L. Gérard, C. Fieschi et al., "Infections in 252 patients with common variable immunodeficiency," Clinical Infectious Diseases, vol. 46, no. 10, pp. 1547-1554, 2008.

[9] H. Chapel, M. Lucas, M. Lee et al., "Common Variable immunodeficiency disorders: division into distinct clinical phenotypes," Blood, vol. 112, no. 2, pp. 277-286, 2008.

[10] A. Durandy, S. Kracker, and A. Fischer, "Primary antibody deficiencies," Nature Reviews Immunology, vol. 13, no. 7, pp. 519533, 2013.

[11] L. Bezrodnik, M. I. Gaillard, and D. Carelli, "Clinical and immunological assessment of 94 patients with primary humoral immunodeficiency: common variable immunodeficiency, selective IgA deficiency and polysaccharide antibody deficiency syndrome," Journal of Pediatric Infectious Diseases, vol. 6, no. 3, pp. 159-166, 2011.

[12] B. Grimbacher, K. Warnatz, and H.-H. Peter, "The immunological synapse for B-cell memory: the role of the ICOS and its ligand for the longevity of humoral immunity," Current Opinion in Allergy and Clinical Immunology, vol. 3, no. 6, pp. 409-419, 2003.

[13] M. C. van Zelm, I. Reisli, M. Van Der Burg et al., "An antibodydeficiency syndrome due to mutations in the CD19 gene," New England Journal of Medicine, vol. 354, no. 18, pp. 1901-1912, 2006.

[14] H. Kanegane, K. Agematsu, T. Futatani et al., "Novel mutations in a Japanese patient with CD19 deficiency," Genes and Immunity, vol. 8, no. 8, pp. 663-670, 2007.

[15] T. W. Kuijpers, R. J. Bende, P. A. Baars et al., "CD20 deficiency in humans results in impaired $\mathrm{T}$ cell-independent antibody responses," Journal of Clinical Investigation, vol. 120, no. 1, pp. 214-222, 2010.

[16] M. C. van Zelm, J. Smet, B. Adams et al., "CD81 gene defect in humans disrupts CD19 complex formation and leads to antibody deficiency," The Journal of Clinical Investigation, vol. 120, no. 4, pp. 1265-1274, 2010.

[17] K. Warnatz, U. Salzer, M. Rizzi et al., "B-cell activating factor receptor deficiency is associated with an adult-onset antibody deficiency syndrome in humans," Proceedings of the National Academy of Sciences of the United States of America, vol. 106, no. 33, pp. 13945-13950, 2009.

[18] U. Salzer, H. M. Chapel, A. D. B. Webster et al., "Mutations in TNFRSF13B encoding TACI are associated with common variable immunodeficiency in humans," Nature Genetics, vol. 37, no. 8, pp. 820-828, 2005.

[19] E. Castigli, S. A. Wilson, L. Garibyan et al., "TACI is mutant in common variable immunodeficiency and IgA deficiency," Nature Genetics, vol. 37, no. 8, pp. 829-834, 2005.

[20] Q. Pan-Hammarström, U. Salzer, L. Du et al., "Re-examining the role of TACI coding variants in common variable immunodeficiency and selective IgA deficiency," Nature Genetics, vol. 39, no. 4, pp. 429-430, 2007.

[21] U. Salzer, C. Bacchelli, S. Buckridge et al., "Relevance of biallelic versus monoallelic TNFRSF13B mutation variants," Blood, vol. 113, no. 9, pp. 1967-1976, 2009.

[22] M. E. Conley, "Genetics of hypogammaglobulinemia: what do we really know?" Current Opinion in Immunology, vol. 21, no. 5, pp. 466-471, 2009.

[23] M. B. Almejún, E. Sajaroff, M. Galicchio et al., "Immunological characteristics and two novel mutations in TACI in a cohort of 28 pediatric patients with common variable immunodeficiency," Journal of Clinical Immunology, vol. 32, no. 1, pp. 89-97, 2012.

[24] R. Morita, N. Schmitt, S.-E. Bentebibel et al., "Human blood $\mathrm{CXCR}^{+} \mathrm{CD}^{+} \mathrm{T}$ cells are counterparts of $\mathrm{T}$ follicular cells and contain specific subsets that differentially support antibody secretion," Immunity, vol. 34, no. 1, pp. 108-121, 2011.

[25] L. Bossaller, J. Burger, R. Draeger et al., "ICOS deficiency is associated with severe reduction of $\mathrm{CXCR}^{+} \mathrm{CD} 4$ germinal center Th cells," The Journal of Immunology, vol. 177, no. 7, pp. 4927-4932, 2006.

[26] N. Simpson, P. A. Gatenby, A. Wilson et al., "Expansion of circulating $\mathrm{T}$ cells resembling follicular helper $\mathrm{T}$ cells is a fixed phenotype that identifies a subset of severe systemic lupus erythematosus," Arthritis and Rheumatism, vol. 62, no. 1, pp. 234-244, 2010. 
[27] M. E. Keir, M. J. Butte, G. J. Freeman, and A. H. Sharpe, "PD1 and its ligands in tolerance and immunity," Annual Review of Immunology, vol. 26, pp. 677-704, 2008.

[28] S. D. Blackburn, H. Shin, W. N. Haining et al., "Coregulation of CD8+ T cell exhaustion by multiple inhibitory receptors during chronic viral infection," Nature Immunology, vol. 10, no. 1, pp. 29-37, 2009.

[29] D. M. Dorfman, J. A. Brown, A. Shahsafaei, and G. J. Freeman, "Programmed death-1 (PD-1) is a marker of germinal centerassociated T cells and angioimmunoblastic T-cell lymphoma," The American Journal of Surgical Pathology, vol. 30, no. 7, pp. 802-810, 2006.

[30] K. L. Good-Jacobson, C. G. Szumilas, L. Chen, A. H. Sharpe, M. M. Tomayko, and M. J. Shlomchik, "PD-1 regulates germinal center B cell survival and the formation and affinity of longlived plasma cells," Nature Immunology, vol. 11, no. 6, pp. 535542, 2010.

[31] E. Hams, M. J. McCarron, S. Amu et al., "Blockade of B7-H1 (programmed death ligand 1) enhances humoral immunity by positively regulating the generation of T follicular helper cells," Journal of Immunology, vol. 186, no. 10, pp. 5648-5655, 2011.

[32] J. He, L. M. Tsai, Y. A. Leong et al., "Circulating precursor CCR7lo PD-1hi CXCR5 ${ }^{+} \mathrm{CD}^{+}{ }^{\mathrm{T}}$ cells indicate Tfh cell activity and promote antibody responses upon antigen reexposure," Immunity, vol. 39, no. 4, pp. 770-781, 2013.

[33] M. A. Linterman, W. Pierson, S. K. Lee et al., "Foxp3+ follicular regulatory T cells control the germinal center response," Nature Medicine, vol. 17, no. 8, pp. 975-982, 2011.

[34] A. Noble, A. Giorgini, and J. A. Leggat, "Cytokine-induced IL10-secreting CD8 T cells represent a phenotypically distinct suppressor T-cell lineage," Blood, vol. 107, no. 11, pp. 4475-4483, 2006.

[35] B. Ruibal-Ares, L. Belmonte, P. Baré et al., "Monocyte differentiation and HIV replication after prolonged culture of peripheral blood mononuclear cells from HIV-infected individuals," Cellular Immunology, vol. 210, no. 1, pp. 11-20, 2001.

[36] A. Coraglia, M. Felippo, P. Schierloh, A. Malbran, and M. M. de E de Bracco, "CD4+ T lymphocytes with follicular helper phenotype $\left(\mathrm{T}_{\mathrm{FH}}\right)$ in patients with SH2D1A deficiency (XLP)," Clinical Immunology, vol. 141, no. 3, pp. 357-364, 2011.

[37] A. Malbrán, M. C. Juri, and D. S. Fernández Romero, "Common variable immunodeficiency and granulomatosis treated with infliximab," Clinical Immunology, vol. 134, no. 3, pp. 359-360, 2010.

[38] C. Wehr, T. Kivioja, C. Schmitt et al., "The EUROclass trial: defining subgroups in common variable immunodeficiency," Blood, vol. 111, no. 1, pp. 77-85, 2008.

[39] K. Warnatz, A. Denz, R. Dräger et al., "Severe deficiency of switched memory B cells $\left(\mathrm{CD}^{2} 7^{+} \operatorname{IgM}^{-} \operatorname{IgD}^{-}\right)$in subgroups of patients with common variable immunodeficiency: a new approach to classify a heterogeneous disease," Blood, vol. 99, no. 5, pp. 1544-1551, 2002.

[40] M. Rakhmanov, B. Keller, S. Gutenberger et al., "Circulating CD21 low B cells in CVID resemble tissue homing, innate-like B cells," Proceedings of the National Academy of Sciences of the United States of America, vol. 106, no. 32, pp. 13451-13456, 2009.

[41] I. Isnardi, Y.-S. Ng, L. Menard et al., "Complement receptor 2/CD21- human naive B cells contain mostly autoreactive unresponsive clones," Blood, vol. 115, no. 24, pp. 5026-5036, 2010.
[42] D. L. Barber, E. J. Wherry, D. Masopust et al., "Restoring function in exhausted CD8 T cells during chronic viral infection," Nature, vol. 439, no. 7077, pp. 682-687, 2006.

[43] P. T. Sage, L. M. Francisco, C. V. Carman, and A. H. Sharpe, "The receptor PD-1 controls follicular regulatory T cells in the lymph nodes and blood," Nature Immunology, vol. 14, no. 2, pp. 152-161, 2013.

[44] V. Thon, H. M. Wolf, M. Sasgary et al., "Defective integration of activating signals derived from the $\mathrm{T}$ cell receptor (TCR) and costimulatory molecules in both $\mathrm{CD}^{+}$and $\mathrm{CD}^{+} \mathrm{T}$ lymphocytes of common variable immunodeficiency (CVID) patients," Clinical and Experimental Immunology, vol. 110, no. 2, pp. 174-181, 1997.

[45] M. B. Fischer, I. Hauber, H. Eggenbauer et al., "A defect in the early phase of T-cell receptor-mediated T-cell activation in patients with common variable immunodeficiency," Blood, vol. 84, no. 12, pp. 4234-4241, 1994.

[46] V. Thon, H. Eggenbauer, H. M. Wolf et al., "Antigen presentation by common variable immunodeficiency (CVID) B cells and monocytes is unimpaired," Clinical and Experimental Immunology, vol. 108, no. 1, pp. 1-8, 1997.

[47] E. K. Deenick and S. G. Tangye, "IL-21: a new player in Th17-cell differentiation," Immunology and Cell Biology, vol. 86, no. 5, p. 478, 2008.

[48] D. Yu and C. G. Vinuesa, "Multiple checkpoints keep follicular helper T cells under control to prevent autoimmunity," Cellular and Molecular Immunology, vol. 7, no. 3, pp. 198-203, 2010.

[49] M. A. Linterman, R. J. Rigby, R. K. Wong et al., "Follicular helper T cells are required for systemic autoimmunity," Journal of Experimental Medicine, vol. 206, no. 3, pp. 561-576, 2009.

[50] J. S. Weinstein, S. G. Hernandez, and J. Craft, "T cells that promote B-Cell maturation in systemic autoimmunity," Immunological Reviews, vol. 247, no. 1, pp. 160-171, 2012.

[51] L. D. DiPlacido and J. Craft, "Emerging from the shadows: follicular helper T cells in autoimmunity," Arthritis and Rheumatism, vol. 62, no. 1, pp. 6-8, 2010.

[52] M. G. Seidel, "Autoimmune and other cytopenias in primary immunodeficiencies: pathomechanisms, novel differential diagnoses, and treatment," Blood, vol. 124, no. 15, pp. 23372344, 2014.

[53] H.-J. Ko, H. Yang, J.-Y. Yang et al., "Expansion of Tfh-like cells during chronic Salmonella exposure mediates the generation of autoimmune hypergammaglobulinemia in MyD88-deficient mice," European Journal of Immunology, vol. 42, no. 3, pp. 618628, 2012. 


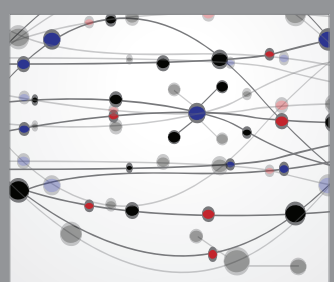

The Scientific World Journal
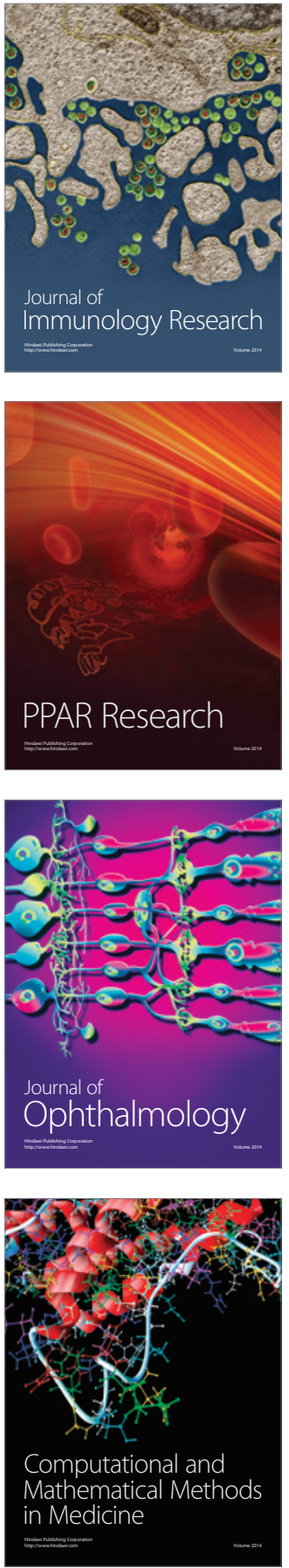

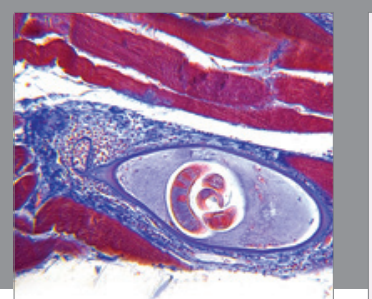

Gastroenterology Research and Practice

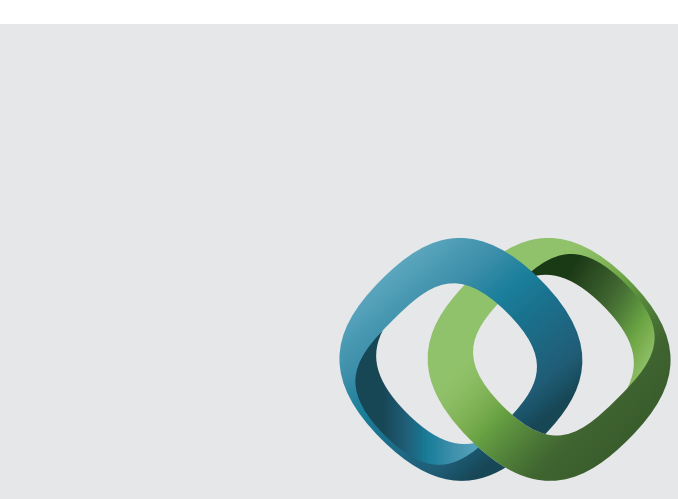

\section{Hindawi}

Submit your manuscripts at

http://www.hindawi.com
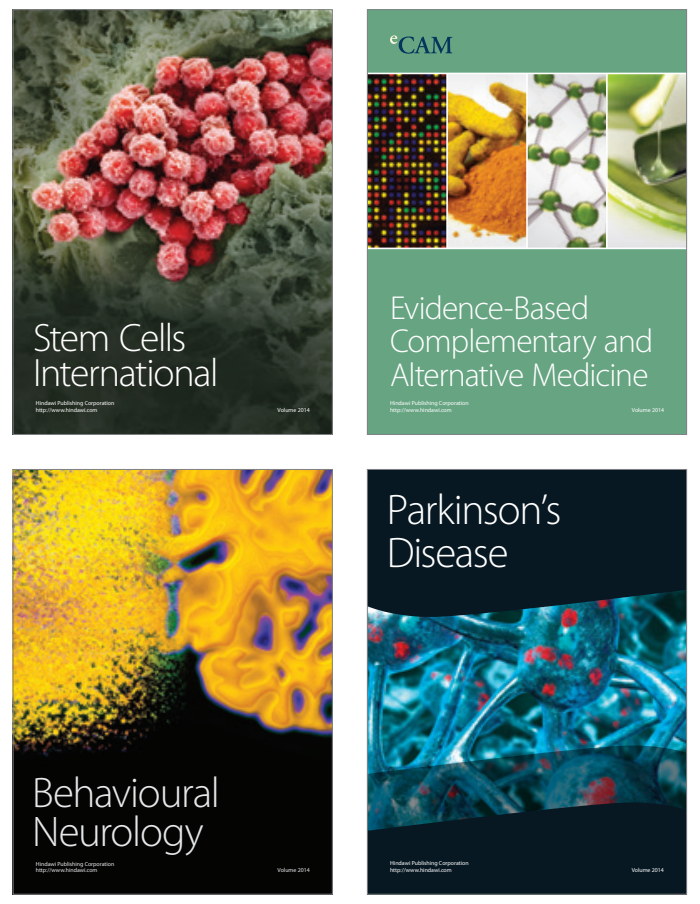
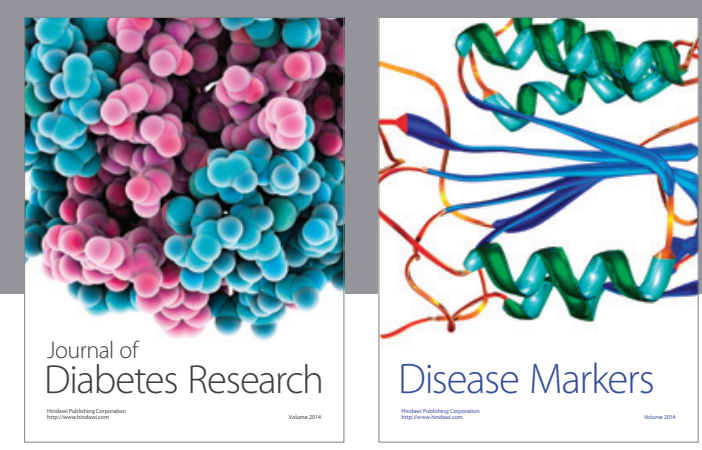

Disease Markers
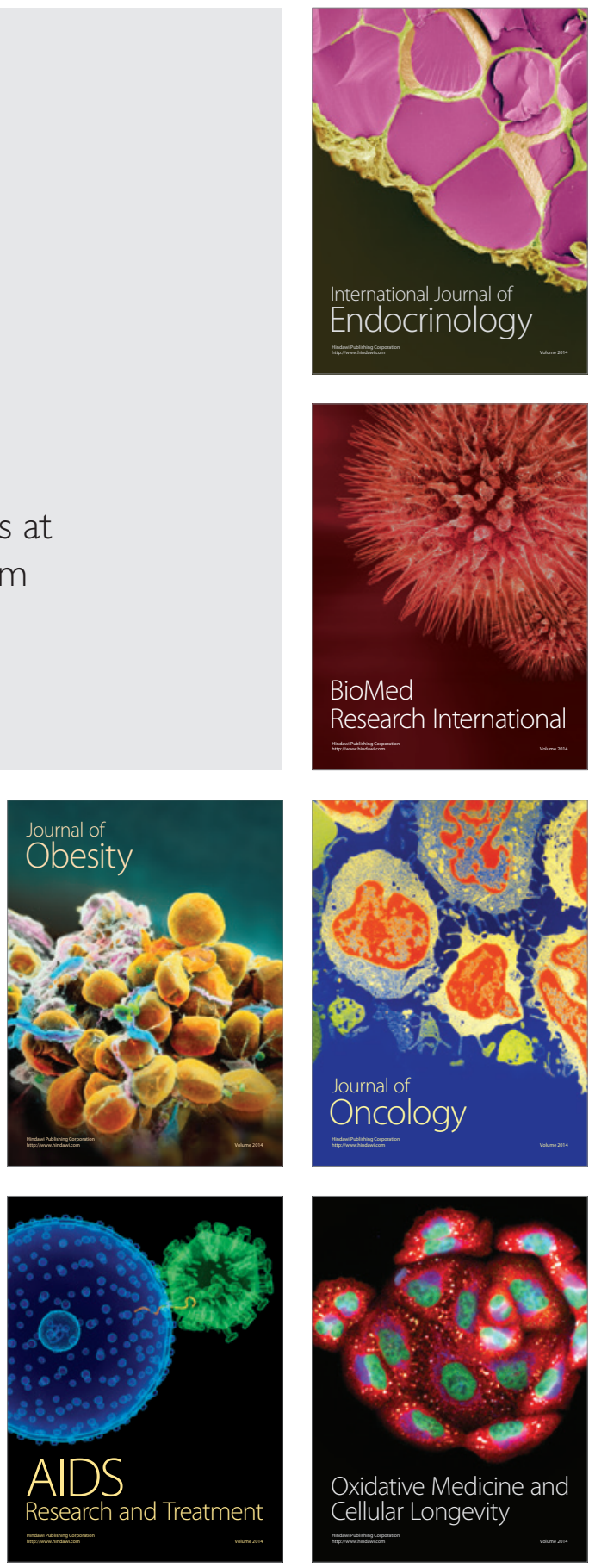